\title{
THE DISCOVERY OF GREAT BASIN BRISTLECONE PINE, PINUS LONGAEVA, IN THE TUSHAR MOUNTAINS OF THE FISHLAKE NATIONAL FOREST IN CENTRAL UTAH, USA
}

\author{
Andrew Orlemann ${ }^{1}$, Steven H. Flinders ${ }^{1}$, and Loreen Allphin²
}

\begin{abstract}
In this paper, we provide the first documented evidence of Pinus longaeva from the Tushar Mountain range in central Utah. The P. longaeva trees, initially noticed at the end of September, and further surveyed during the first week of October 2016 are present on 6 small sites on the north-facing slopes of the North Fork of North Creek in the Tushar Mountains of the Fishlake National Forest. We estimate that there are currently up to 179 live individuals that range in age from seedlings to approximately 1400 years. Our data indicate these are particularly slow-growing specimens on very steep sites, in soil of igneous origin. Though many of the trees are infested with dwarf mistletoe, there is little indication that the population is currently at risk from fire, bark beetle attack, or many other common pathogens characteristic of other Pinus species. Nonetheless, there may be reasons for concern associated with future changes to the climate of southern Utah, as well as the impact of invasive species such as white pine blister rust (Cronartium ribicola). We see opportunities for additional research on this unique population and its associated plant community. We also see the need for management strategies to conserve these $P$. longaeva stands, as well as a possible need to preserve its seeds and/or other genetic materials.
\end{abstract}

Resumen.-En este artículo, proporcionamos la primera evidencia documentada de Pinus longaeva de la cordillera Tushar, en el centro de Utah. Los árboles de P. longaeva, inicialmente observados a finales de septiembre, y luego estudiados durante la primera semana de octubre del 2016, están presentes en seis pequeños sitios de las laderas orientadas al norte de North Fork de North Creek, en las Montañas Tushar del Bosque Nacional Fishlake. Estimamos que hay actualmente hasta 179 individuos vivos que varían en edad, desde semillas hasta aproximadamente 1400 años. Nuestros datos indican que se trata de especímenes de un lento crecimiento en sitios muy empinados, y en suelos de origen ígneo. Aunque muchos de estos árboles están infestados con muérdago enano, hay pocos indicios de que la población esté actualmente en riesgo de incendio, ataques de escarabajo de corteza o muchos otros patógenos comunes característicos de otras especies de Pinus. No obstante, puede haber motivos de preocupación asociados con futuros cambios climático en el sur de Utah, así como el impacto de las especies invasoras tales como la del hongo conocido como ampolla oxidada de pino blanco (Cronartium ribicola). Vemos oportunidades para llevar a cabo investigaciones adicionales sobre esta singular población y su comunidad de plantas asociada. También vemos la necesidad de implementar estrategias para conservar estos sitios en donde se encuentra $P$. longaeva, así como la posible necesidad de conservar sus semillas y/u otros materiales genéticos.

While bristlecone or foxtail pines have been known to science since the middle of the 19th century, all of these pines were circumscribed under the name Pinus aristata Engelmann in subsection Balfourinae. It was not until 1970 that D.K. Bailey distinguished the "Rocky Mountain Bristlecone Pine" (Pinus aristata Engelmann) from the "Great Basin Bristlecone Pine” (Pinus longaeva D.K. Bailey; Bailey 1970). This group is now recognized as 3 distinct species (Bailey 1970): the bristlecone pines ( $P$. aristata and $P$. longaeva) and the foxtail pine (Pinus balfouriana Balf.), made up of 2 subspecies (subsp. balfourina and austrina R. Mastrog. and J. Mastrog.; Mastrogiuseppe and Magstrogiuseppe 1980).
In the mid-1950s, Edmund P. Schulman studied bristlecone pines in the White Mountains of California and discovered that they live for nearly 5000 years (Straka 2008). Indeed, $P$. longaeva has been called the oldest living thing on earth (Beasley and Klemmedson 1973), although at the locations most commonly studied in southern Utah (on the Markagunt and Table Cliffs Plateaus) individual trees do not exceed about 2000 years of age (Connor and Lanner 1990). Along with the tree itself, the leaves of $P$. longaeva are also long-lived, often being retained for decades and providing information about summer air temperatures (LaMarche and Stockton 1974). For the purposes of studying the past, however, even dead

\footnotetext{
${ }^{1}$ Beaver Ranger District, Fishlake National Forest, United States Department of Agriculture, Box E, Beaver, UT 84713.

${ }^{2}$ Corresponding author. Department of Plant and Wildlife Sciences, 4105 LSB, Brigham Young University, Provo, UT 84602. E-mail: loreen_allphin@byu.edu
} 
bristlecone pines are of great value because the wood tends to resist decay for thousands of years (LaMarche and Mooney 1972). As a result, important multicentury environmental chronologies have been built by $P$. longaeva researchers, including some recent work which points to a significant warming of the tree line environment (Salzer et al. 2009, Ziaco et al. 2014, Hallman and Arnott 2015).

While $P$. longaeva is relatively rare, it is not endangered, and its current population trend is considered stable (Stritch et al. 2011). Recent work has demonstrated that the taxon may be better defended against the attacks of the mountain pine beetle (Dendroctonus ponderosae) than are other pines, such as ponderosa pine (Pinus ponderosa) and limber pine (Pinus flexilis). Nonetheless, the risk to small populations of $P$. longaeva from white pine blister rust (Cronartium ribicola) provides a reason for concern; fortunately, this rust has not yet been detected in Utah (Schoettle and Sniezko 2007).

Pinus longaeva is most often found on calcareous sedimentary substrates such as limestone or dolomite, but can occasionally occupy sites dominated by igneous rock, though such individuals are typically restricted to northfacing ridges (Van de Ven et al. 2007). Because soils are often thin and sites droughty, P. longaeva stands do not tend to accumulate hazardous fuels, and stand dynamics are not thought to be shaped by fire (Bradley et al. 1992). Site establishment may, however, be shaped by birds. Lanner (1988) has noted that $P$. longaeva, despite producing relatively small, winged seeds, is primarily dispersed by the seed-caching behavior of the Clark's Nutcracker (Nucifraga columbiana).

In 1970, Bailey published a distribution map for P. longaeva (Bailey 1970) that included much of southeastern Nevada and west central Utah. In addition to the outline of the area of geographical distribution, Bailey's (1970) map included points (selected stations) where stands or even individual trees had been located by botanists. While the Tushar Mountain Range of central Utah was within Bailey's polygon for the geographic distribution of the species, there were no data points associated with the Tushar Mountain Range (Bailey 1970).

In the nearly 5 decades since Bailey published his findings, there have been, to our knowledge, no additions to the botanical literature indicating the presence of $P$. longaeva in the Tushar Range. In 1978, Kay and Oviatt (1978) extended Bailey's original geographic distribution northward in Utah, but we found no records of $P$. longaeva populations located in the Tushar Mountains. Very recently, Bentz et al. (2016) published a study of the susceptibility of $P$. longaeva to mountain pine beetle attack. In that study, the authors included a distribution map for the taxon based on their review of the published literature. Once again, the Tushar Mountains were not present on the Bentz et al. (2016) distribution map, confirming our own literature review.

At the end of September 2016, while descending to the North Fork of North Creek from the south ridge of the canyon, we noticed the telltale bottlebrush branching habit of bristlecone pines on a steep north-facing ledge. It is the first time, to our knowledge, that $P$. longaeva has been identified in the Tushar Range. We subsequently returned in the first week of October 2016 to more thoroughly survey the area for P. longaeva. We confirmed the presence of several small groves of $P$. longaeva on 5 sub-ridges of the main ridge separating North Fork of North Creek from South Fork in the Tushar Mountains of the Fishlake National Forest. In sum, we believe this is the first written account of a $P$. longaeva population for the Tushar Mountains.

\section{Bristlecone Pine in the Tushar Range}

Sites AND Distribution.- - North Fork of North Creek in the Tushar Mountains of the Fishlake National Forest flows from the steep avalanche chutes below the west face of Mt. Baldy $(3695 \mathrm{~m})$ to its confluence with the South Fork in the foothills of the Beaver Valley. The dramatic canyon of North Fork has, for at least the past hundred years, been heavily wooded, its steep slopes cloaked in Douglasfir (Pseudotsuga menziesii), white fir (Abies concolor), aspen (Populus tremuloides), ponderosa pine, and limber pine. In the fall of 2010, however, much of that forest was consumed by the Twitchell Canyon Fire, leaving thousands of acres of standing deadwood in the canyon. Whether such stand-replacing fires are always desirable is certainly open to debate, but, in this case, one benefit was greater visibility throughout the watershed. With the more open conditions, travel along 


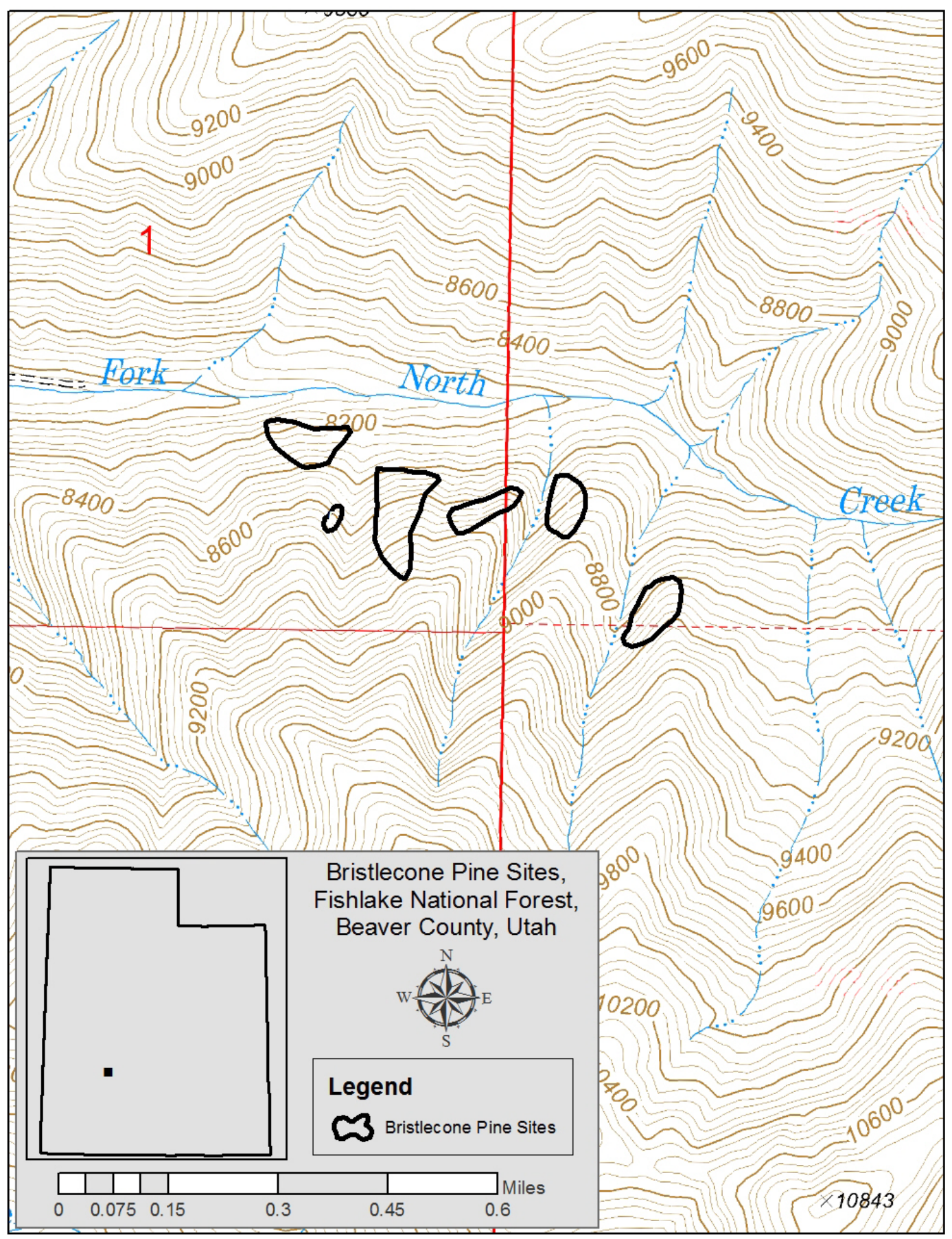

Fig. 1. Polygons of Pinus longaeva sites in the canyon of the North Fork of North Creek in the Tushar Mountains of the Fishlake National Forest, Beaver County, Utah, USA. Map was generated using ArcGIS (Esri, Redlands, CA). 
Table 1. Site characteristics from 6 localities of newly discovered Pinus longaeva in the North Fork of North Creek in the Tushar Mountains, Fishlake National Forest, Beaver County, Utah, USA. ac $=$ acre.

\begin{tabular}{|c|c|c|c|c|}
\hline Site & Estimated size & $\begin{array}{l}\text { Estimated number } \\
\text { of living } P \text {. longaeva }\end{array}$ & Max. elevation (m) & Min. elevation $(\mathrm{m})$ \\
\hline One & $1.1 \mathrm{ha}(2.8 \mathrm{ac})$ & 52 & 2743 & 2688 \\
\hline Two & 0.9 ha $(2.2 \mathrm{ac})$ & 18 & 2667 & 2581 \\
\hline Three & $0.7 \mathrm{ha}(1.8 \mathrm{ac})$ & 20 & 2682 & 2609 \\
\hline Four & $2.0 \mathrm{ha}(5.0 \mathrm{ac})$ & 30 & 2734 & 2557 \\
\hline Five & $0.1 \mathrm{ha}(0.3 \mathrm{ac})$ & 5 & 2649 & 2603 \\
\hline Six & $1.2 \mathrm{ha}(3.0 \mathrm{ac})$ & 54 & 2566 & 2478 \\
\hline TOTAL & $6.1 \mathrm{ha}(15.2 \mathrm{ac})$ & 179 & 2743 & 2478 \\
\hline
\end{tabular}

Table 2. Soil characteristics from a composite soil sample taken across the 6 sites in North Fork of North Creek in the Tushar Mountains, Fishlake National Forest, Beaver County, Utah, USA.

\begin{tabular}{lc}
\hline Soil characteristic & Mean value \\
\hline Texture classification & Loam \\
\% Sand & 33.4 \\
\% Clay & 24.1 \\
\% Silt & 42.4 \\
\% Organic matter & 3.3 \\
pH & 6.9 \\
Electrical conductivity $(\mathrm{dS} / \mathrm{m})$ & 0.2 \\
$\mathrm{NO} \mathrm{O}_{3} \mathrm{~N}(\mathrm{ppm})$ & 5.2 \\
$\mathrm{Ca}(\mathrm{ppm})$ & 17.3 \\
$\mathrm{Fe}(\mathrm{ppm})$ & 37.7 \\
$\mathrm{~K}(\mathrm{ppm})$ & 7.4 \\
$\mathrm{Mg}(\mathrm{ppm})$ & 7.2 \\
$\mathrm{Mn}(\mathrm{ppm})$ & 0.8 \\
$\mathrm{Na}(\mathrm{ppm})$ & 2.6 \\
$\mathrm{P}(\mathrm{ppm})$ & 0.6 \\
$\mathrm{~S}(\mathrm{ppm})$ & 1.1 \\
$\mathrm{Si}(\mathrm{ppm})$ & 2.0 \\
$\mathrm{Sr}(\mathrm{ppm})$ & 0.1 \\
$\mathrm{Ti}(\mathrm{ppm})$ & 1.4 \\
$\mathrm{Zn}(\mathrm{ppm})$ & 0.3 \\
\hline
\end{tabular}

the ridges became possible, eventually leading to the discovery of $P$. longaeva at several sites on the north-facing slopes above the creek. In general, these sites were so rocky and devoid of ladder fuels that they were not impacted by the crown fire. Instead, ground fire crept through the sites, burning some of the scattered, downed wood.

After we surveyed this area in North Fork of North Creek, we divided the newly identified trees into 6 groups, or sites, based on their position on the landscape (Fig. 1, Table 1). Starting from the east end, we labeled the sites, one through six. Each site was separated from the next by an avalanche chute or talus slope along with a northeast-facing sub-ridge (Fig. 1). From the top of the sub-ridge, working down and toward the west, nearly all of the sites were on the steep northwest-facing slopes-the only exception being tiny site five which tilts slightly to the northeast. While inspecting these sites, we determined that they were, in general, steeper than we could safely traverse, with slopes ranging from $70 \%$ to $80 \%$ or more. Many of the P. longaeva trees were growing directly from vertical ledges, and to measure them individually likely would have required us to set up a rappel.

According to the USGS (Rowley et al. 2002), these ledges are composed of the Mount Baldy Rhyolite Member, an extrusive igneous rock: "Resistant, light-gray, flow foliated, crystal-poor intra-caldera rhyolite lava flows and dikes derived from, and deposited mostly within, the Mount Belknap caldera." Because $P$. longaeva typically demonstrates a preference for calcareous sedimentary rock, we speculate that its presence in what is essentially a lava field is due to some combination of slope, elevation, and aspect, giving it, if not a competitive advantage, at least an even chance against the persistent encroachment of the shade-tolerant firs.

We collected a composite soil sample from each of the 6 sites in North Fork of North Creek. We analyzed this soil for texture, $\mathrm{pH}$, salinity, nitrates, organic matter, and several elemental nutrients. Soil analyses were performed by the Environmental Analytical Laboratory at Brigham Young University (Table 2). From these analyses, we note that the soils are loams, with relatively neutral pH and low salinity (Table 2). The soils are nutrient poor, with few nitrates, little organic matter, and low levels of elemental nutrients (Table 2). The soil characteristics are consistent with rocky, igneous soils and atypical of $P$. longaeva's preference for calcareous, sedimentary rock (Van de Ven et al. 2007). The soils at the Tusher sites also contain less sand, lower $\mathrm{pH}$, and less organic matter 
TABLE 3. A sampling of individual tree characteristics from Pinus longaeva sites in the Tushar Mountains, Fishlake National Forest, Beaver County, Utah, USA.

\begin{tabular}{|c|c|c|c|c|c|c|c|}
\hline Site & $\begin{array}{c}\text { No. of trees } \\
\text { sampled }\end{array}$ & $\begin{array}{c}\text { Elevation } \\
(\mathrm{m})\end{array}$ & $\begin{array}{c}\text { Diameter } \\
(\mathrm{cm})\end{array}$ & $\begin{array}{l}\text { Height } \\
\text { (m) }\end{array}$ & $\begin{array}{c}\text { Pith } \\
\text { reached?a }\end{array}$ & $\begin{array}{l}\text { Annual radial } \\
\text { growth or ring } \\
\text { width }(\mathrm{mm})\end{array}$ & $\begin{array}{c}\text { Estimated } \\
\text { germination } \\
\text { (year) }\end{array}$ \\
\hline One & 2 & 2686 & 40.6 & 11 & Yes (1) & 0.39 & 1530 \\
\hline Two & 2 & 2622 & 28.2 & 11.3 & Yes (2) & 0.26 & 1540 \\
\hline Three & 1 & 2645 & 74.4 & 11.3 & No & 0.47 & 1225 \\
\hline Four & 1 & 2655 & 44.7 & 4.9 & No & 0.29 & 1245 \\
\hline Five & 1 & 2526 & 88.9 & 13.7 & No & 0.31 & 584 \\
\hline Six & 1 & 2478 & 42.4 & 6.1 & No & 0.2 & 956 \\
\hline
\end{tabular}

aThe number in parentheses indicates the number of samples for which the pith was reached.

than soils of $P$. longaeva at Charleston Peak, Nevada (Weiss et al. 2005).

For each site, we also estimated the number of living individuals of $P$. longaeva, and using ArcGIS we derived minimum and maximum elevation and developed a polygon which encompassed all P. longaeva (Fig. 1, Table 1). Additionally, we qualitatively surveyed the rest of the forest at each site. In general, these stands are composed of white fir, limber pine, quaking aspen, Douglas-fir, and ponderosa pine, in roughly that order of dominance. Of particular interest was the relative abundance of young limber pine on these harsh sites vis-à-vis $P$. longaeva, a shift in dominance that has been noted elsewhere (Millar et al. 2006).

Despite the steep, rocky nature of these sites, the understory shrub and forb communities are relatively diverse. We noted more than a dozen species on each site, and this list is by no means exhaustive: chokecherry (Prunus virginiana), Oregon grape (Mahonia repens), snowberry (Symphoricarpos oreophilus), manzanita (Arctostaphylos patula), penstemon (Penstemon sp.), Woods' rose (Rosa woodsii), Tushar mat penstemon (Penstemon tusharensis), geranium (Geranium caespitosum), mountain lover (Paxistima myrsinites), elderberry (Sambucus caerulea), mullein (Verbascum thapsus), common juniper (Juniperus communis), and Rocky Mountain maple (Acer glabrum). It's also worth noting that although these sites were only mildly affected by the Twitchell Canyon Fire, there are scattered fire-killed $P$. longaeva individuals on the slopes outside of our identified sites. We speculate that this may point to greater pre-Twitchell Canyon Fire continuity between sites, though we did not attempt to estimate the number (or location) of $P$. longaeva killed by the fire.

The majority of the P. longaeva trees that we observed on our 5 sites are small (Table 3 ).
The tallest of them is $<14 \mathrm{~m}$ in height and, on average, they are more likely to be only about $10 \mathrm{~m}$ tall, or less. We measured several diameters (DBH, diameter at breast height) and found the trees to be, on average, around $50 \mathrm{~cm}$ (19-20 inches) DBH, Table 3. Many of these small trees are multistemmed, and should probably be measured at the root collar. However, our trees were taller and larger than those in the Snake Range in East Central Nevada (mean DBH, $30 \mathrm{~cm}$; mean tree height, $7 \mathrm{~m}$; Ziaco et al. 2014). In addition, most of the larger-diameter trees have partial, if not nearly complete, cambium mortality. Moreover, nearly every specimen that we observed is infested with dwarf mistletoe, which we took to be Arceuthobium cyanocarpum (Taylor and Mathiasen 2002), and large witches' brooms are common. In sum, these are typical $P$. longaeva trees on difficult sites-not exactly krummholz-shaped, but certainly stunted, battered, and ragged looking.

TREE AGE.-Using an increment borer, we attempted to remove a pair of core samples from at least one accessible tree on each site. We use the term "attempted" because we were only rarely successful. Of 14 samples from 8 trees, only 5 verifiably reached the pith. Despite the absence of external evidence of wounding, most of the selected trees were rotted at the center. Thus, at least 9 of our samples ended in sawdust after turning the increment borer through approximately a dozen centimeters of solid wood.

Nonetheless, following Speer (2010), we air-dried, mounted, and sanded the cores. In the lab, we dated the results, starting from the bark. Because the cores were taken from live trees and because the 2016 rings were clear, we were able to count a complete set of growth rings for several of our samples (Table $3)$. From the first sampled tree (tree one on 
site one), we obtained one complete core, from bark to pith, while the second sample crumbled near the pith (Table 3). It was enough to estimate a germination date circa 1530 and a mean annual radial growth rate (ring width) of $0.39 \mathrm{~mm}$ (Table 3). However, many of our additional samples ended in heart rot. Because of time and equipment constraints, we did not cross-date our cores. For those trees without a complete core, we estimated germination dates by extrapolating the mean annual growth rate out to the full known diameter (Hiebert and Hamrick 1983).

Pinus longaeva are known to be slowgrowing trees, but our ring widths appear to be particularly narrow (Table 2). From 14 samples, we obtained a mean ring width of $0.32 \mathrm{~mm}$ (SD 0.09, median $0.30 \mathrm{~mm}$; Table 3). Based on this small sample, we are $95 \%$ confident that the average ring width of these $P$. longaeva individuals is between $0.27 \mathrm{~mm}$ and $0.37 \mathrm{~mm}$ (Table 2). By contrast, Salzer et al. (2009) analyzed thousands of GBBP samples from 3 sites in California and Nevada, which showed a mean ring width of 0.46 (SD 0.07 , median $0.40 \mathrm{~mm}$ ). Likewise, on the nearby Markagunt Plateau, Hiebert and Hamrick (1983) sampled 112 P. longaeva and obtained a ring width of $0.432 \mathrm{~mm}$ (which they published as an average annual growth rate of $0.864 \mathrm{~mm}$ of diameter). We do not speculate on the reasons for these slow growth rates, other than to say that we found no mention of heavy mistletoe infestations in the previous studies (Hiebert and Hamrick 1983).

Along with the living $P$. longaeva trees on the Tushar Mountain sites, there are numerous picturesque $P$. longaeva skeletons, both lying on the ground and standing upright. We did not estimate their number, but many of them contain a significant proportion of sound wood. Because many of them are of large girth and have likely been dead for many years, they could, if sampled, provide dendrochronological data extending back many centuries, if not millennia.

\section{Future Considerations}

Climate change.-In order to survive predicted climatic warming, most models show that an upslope migration by $P$. longaeva will be necessary (Van de Ven et al. 2007). While the mechanisms for such a migration in the Tushar Mountains are plentiful (the climate alone may be less important than the lithologic processes that have created these environments), these microsites appear to be the best, if not the only places for this species in the Tushars (Macias-Fauria and Johnson 2013). On the other hand, P. longaeva has survived past climatic changes and has shown an ability to both migrate and adapt. This adaptability may be due to high within-population genetic diversity and long lifespans that allow the $P$. longaeva to withstand habitat changes (Hamrick 2004).

Management.-The USDA Forest Service is a multiple-use agency, whose mission includes active forestry treatments in managed forest stands. In this case, however, there is little scope for direct silvicultural intervention because the sites are relatively inaccessible. However, future management might include several considerations: First, merely being aware of this small population of bristlecone pine will allow managers to protect it from future perturbations (i.e., from direct application of prescribed fire). Second, working in conjunction with geneticists and nursery managers in the intermountain region, it may be possible to collect, preserve, and bank (or plant) seeds from this population to ensure its continued survival in the Tushar Mountains. Third, the Forest Service supports an active research program, and the discovery of these small groves of $P$. longaeva may spur further studies of dendroclimatology and stand ecology.

\section{Conclusions}

We provide the first documented evidence of P. longaeva from the Tushar Mountain range in central Utah. Our data indicate that these individuals are particularly slow-growing specimens on very steep sites and on soils of igneous origin. Though many of the trees are infested with dwarf mistletoe, there is little indication that the population is currently at risk from fire, bark beetle attack, or other common pathogens characteristic of other Pinus species. Nonetheless, future climate change in southern Utah may be of concern, as well as the impact of invasive species such as white pine blister rust. We see opportunities for additional research on this unique population and its associated plant community. We also see the need for management strategies to preserve these $P$. longaeva stands, as well as a possible need to preserve its seeds and/or other genetic materials. 


\section{Literature Cited}

BAILEY, D.K. 1970. Phytogeography and taxonomy of Pinus subsection Balfourianae. Annals of the Missouri Botanical Garden 57:210-249.

Beasley, R.S., and J.O. Klemmedson. 1973. Recognizing site adversity and drought-sensitive trees in stands of bristlecone pine (Pinus longaeva). Economic Botany 27:141-146.

Bentz, B.J., S.M. Hood, E.M. Hansen, J.C. VandygRifF, AND K.E. Моск. 2016. Defense traits in the longlived Great Basin bristlecone pine and resistance to the native herbivore mountain pine beetle. New Phytologist 213:611-624.

Bradley, A., N. Noste, AND W. Fischer. 1992. Fire ecology of forests and woodlands in Utah. General Technical Report INT-287, USDA Forest Service, Intermountain Research Station. 92 pp.

ConNOR, K.F., AND R.M. LANNER. 1990. Effects of tree age on secondary xylem and phloem anatomy in stems of Great Basin bristlecone pine (Pinus longaeva). American Journal of Botany 77:1070-1077.

Hallman, C., AND H. ARnotT. 2015. Morphological and physiological phenology of Pinus longaeva in the White Mountains of California. Tree-Ring Research 71:1-12.

Hamrick, J.L. 2004. Response of forest trees to global environmental changes. Forest Ecology and Management 197:323-335.

Hiebert, R.D., and J.L. Hamrick. 1983. Patterns and levels of genetic variation in Great Basin bristlecone pine, Pinus longaeva. Evolution 37:302-310.

KaY, P.A., and C.G. Oviatt. 1978. Pinus longaeva in the Stansbury Mountains, Utah. Western North American Naturalist 38:49-50.

LaMarche, V.C., Jr., and H.A. Mooney. 1972. Recent climatic change and development of the bristlecone pine (P. longaeva Bailey) krummholz zone, Mt. Washington, Nevada. Arctic and Alpine Research 4:61-72.

LaMarche, V.C., JR., and C.W. StockTON. 1974. Chronologies from temperature-sensitive bristlecone pines at upper treeline in western United States. Tree-Ring Bulletin 34:21-45.

Lanner, R.M. 1988. Dependence of Great Basin bristlecone pine on Clark's nutcracker for regeneration at high elevations. Arctic and Alpine Research 20: 358-362.

Macias-Fauria, M., and E.A. Johnson. 2013. Warminginduced upslope advance of subalpine forest is severely limited by geomorphic processes. Proceedings of the National Academy of Sciences 110: $8117-8122$.
Mastrogiuseppe, R.J., and J.D. Mastrogiuseppe. 1980. A study of Pinus balfouriana Grev. \& Balf. (Pinaceae). Systematic Botany 5:86-104.

Millar, C.I., R.D. Westfall, and D.L. Delany. 2006. Elevational gradients and differential recruitment of limber pine (Pinus flexilis) and bristlecone pine (Pinus longaeva); White Mountains, California, USA. AGU poster: C33C-1289. [Accessed 10 October 2016]. http://www.fs.fed.us/psw/publications/millar/ posters/millar_etal_poster_agu2006.pdf

Rowley, P.D., C. $\bar{G}$. Cunningham, T.A. Steven, J.B. Workman, J.J. Anderson, and K.M. Theissen. 2002. Geologic map of the central Marysvale volcanic field, southwestern Utah. U.S. Geological Survey Geologic Investigations Series I-2645-A.

SAlzer, M.W., M.K. Hughes, A.G. BunN, AND K.F. KipfMUELLER. 2009. Recent unprecedented tree-ring growth in bristlecone pine at the highest elevations and possible causes. Proceedings of the National Academy of Sciences 106:20348-20353.

Schoettle, A.W., and R.A. Sniezko. 2007. Proactive intervention to sustain high-elevation pine ecosystems threatened by white pine blister rust. Journal of Forest Research 12(5):327-336.

SpeER, J.H. 2010. Fundamentals of tree-ring research. University of Arizona Press, Tucson, AZ.

StrakA, T.J. 2008. Biographical portrait: Edmond P. Schulman (1908-1958). Forest History Today 14(4): 46-49.

Stritch, L., M. Mahalovich, and K.G. Nelson. 2011. Pinus longaeva. The IUCN Red List of Threatened Species 2011: e.T34024A9830878. http://dx.doi.org/10 .2305/IUCN.UK.2011-2.RLTS.T34024A9830878.en

Taylor, J.E., and R.L. Mathiasen. 2002. Limber pine dwarf mistletoe. Forest Insect \& Disease Leaflet 171, USDA Forest Service, Washington, DC. 7 pp.

Van de Ven, C.M., S.B. Weiss, and W.G. Ernst. 2007. Plant species distributions under present conditions and forecasted for warmer climates in an arid mountain range. Earth Interactions 11(9):1-33.

Weiss, L., A.B. Shiels, and L.R. Walker. 2005. Soils impacts of bristlecone pine (Pinus longaeva) tree islands on alpine tundra, Charleston Peak, Nevada. Western North American Naturalist 65:536-540.

Ziaco, E., F. Biondi, S. Rossi, and A. Deslauriers. 2014. Climatic influences on wood anatomy and tree-ring features of Great Basin conifers at a new mountain observatory. Applications in Plant Science 2(10). http://dx.doi.org/10.3732/apps.1400054

Received 9 November 2016

Accepted 5 January 2017

Published online 29 March 2017 